\title{
THE USE OF RADIOIODINE IN PHYSIOLOGICAL AND CLINICAL STUDIES ON THE THYROID GLAND
}

\author{
By M. S. RABEN 1 AND E. B. ASTWOOD
}

(From the Joseph H. Pratt Diagnostic Hospital and the Department of Medicine, Tufts Medical School, Boston, Mass.)

The presence of iodine within the molecule of thyroid hormone has greatly facilitated physiological studies on the thyroid gland. In a sense the primary function of the thyroid gland is to regulate the intermediary metabolism of iodine; studies on the fate of iodine in the body, then, bear directly on thyroid physiology. Chemical methods for the detection and quantitative determination of iodine have been developed to a high degree of sensitivity and accuracy, and there are few substances that can be measured by chemical means in such small quantities. The use of radioiodine has not only simplified many procedures which would be most difficult by chemical methods, but it has made it possible to carry out studies which could not have been done by any other means.

First described by Fermi in 1934 (1) radioiodine $\left(\mathrm{I}^{128}\right)$ was first used in physiological studies by Hertz, Roberts, and Evans in 1938 (2). The longer lived isotopes, $\mathrm{I}^{130}$ and $\mathrm{I}^{131}$, more suitable for physiological and clinical experiments, could be produced in limited quantity in the cyclotron and were used in several centers for fundamental investigations. Extensive applications of radioiodine have been possible since 1946 when $I^{181}$ was made in quantity by the chain-reacting uranium pile.

\section{Evidence for physiological identity of radioiodine and $I^{127}$}

By analogy with the isotopes of other elements it was to be expected that radioactive iodine would not differ chemically or in physiological reaction from ordinary iodine. No single experiment with radioiodine establishes this fact, but many observations are consistent with the chemical identity of the several isotopes; no evidence has yet been brought forward to indicate that chemical differences exist. Favoring the supposition that

\footnotetext{
1 Atomic Energy Commission Postdoctoral Research Fellow in the Medical Sciences of the National Research Council.
}

$\mathrm{I}^{131}$ is identical with $\mathrm{I}^{127}$ in chemical and physiological reactions are the observations that: (1) under appropriate conditions exchanges to theoretical equilibrium can be observed between radioiodide and diiodotyrosine and vice versa (3) ; (2) various radioiodine-labelled compounds can be purified to constant specific activity; (3) when physiological experiments are performed using radioactive and chemical methods for iodine in parallel, good agreement is observed; and (4) administered radioactive iodine appears in diiodotyrosine, thyroxine, and protein-bound iodine.

A question which seems not to have been answered, however, concerns the chemical state of the carrier-free iodine which is used in tracer studies. One wonders whether the equilibria which obtain with chemically detectable concentrations of iodine still hold in solutions of almost infinite dilution, and whether one can safely manipulate solutions of carrier-free $\mathrm{I}^{131}$ without fear of unpredictable changes in chemical state. The preparation of this material for administration to man or animal must surely carry the hazard of a partial conversion to hypoiodite or even iodate; and, were this to occur, bizarre results might follow, especially after parenteral use. For these and other reasons the use of carrier would seem advisable whenever there is no contraindication to it.

Similar uncertainties may arise when tissues or body fluids containing radioiodine are subjected to chemical procedures. When carrier cannot be used as in the identification of a new or unknown compound, large errors might enter because of the extreme smallness of the quantities involved.

Considerable debate has concerned the extent to which exchange reactions might complicate physiological studies and thus invalidate conclusions. Leblond and Süe (4) found little or no exchange in vitro upon admixing radioiodine and iodate or radioiodine and diiodotyrosine in aqueous solution. Miller et al. (3), however, 
have defined certain in vitro conditions which are favorable for the exchange between the iodine atoms of diiodotyrosine and iodide or iodine. The reaction is rapid in acid solutions and is accelerated by heat and by oxidative environments which would permit the presence of iodine. At physiological hydrogen ion concentrations, little exchange occurs, and reducing agents are strongly inhibitory. Evidence against the occurrence of simple exchange in vivo, as well as against it taking place during the usual in vitro fractionation procedures on thyroid tissue, has been provided by the experiments of Morton and Chaikoff (5). They showed that although radioiodine was incorporated into diiodotyrosine and thyroxine by surviving thyroid slices, little or no radioiodine entered these compounds when homogenized thyroid tissue was used.

\section{Absorption, distribution, and excretion of iodide ion}

It is usually assumed that iodide ion resembles chloride ion in the rate and extent of its absorption from the intestinal tract and in its distribution in the body fluids. It appears to remain in the extracellular space and to be distributed in the body in a manner which is very similar to chloride and thiocyanate (6). Apparently iodide ion is handled somewhat differently from chloride by the gastric mucosa and the kidney, and, of course, the difference is striking in the case of the thyroid gland. Davenport (7) found that iodide is selectively excreted by the stomach provided the blood concentration is low. As the normal concentration is very low, one would have anticipated that tracer doses of $\mathrm{I}^{131}$ would be selectively excreted into the stomach. This has proved to be the case ( 8$)$, and it is a common observation that shortly after the administration of radioiodine a significantly higher concentration is detectable in the stomach than in other sites, excepting the thyroid and the urine. Marinelli and Hill (9) have calculated that when large doses of $\mathrm{I}^{131}$ are given for the treatment of thyroid tumors, the gastric mucosa receives a large dosage of radiation, even when the radioiodine is given intravenously. A temporary decrease in both gastric and salivary secretion has been noted under these circumstances (10). The kidney, at least in some species, excretes iodide more rapidly than chloride or bromide, and the rate of excretion has been observed to be hastened somewhat by the administration of increased amounts of chloride. This has been strikingly demonstrated recently in the dog. Riggs (11) observed that this species 'excreted iodide very slowly but that the rate of excretion was greatly enhanced by large amounts of either bromide or chloride, and even by large amounts of iodide.

The renal excretion of a tracer dose of $I^{131}$ in man has been extensively investigated. When a large quantity of iodide labelled with radioiodine is given, virtually all of it can be recovered in the urine within a few days. With small doses or tracer amounts only a fraction appears in the urine, a varying proportion entering the thyroid in firm combination with protein. Hamilton and Soley (12) found that 53 to 81 per cent of a $14 \mathrm{mg}$. dose was excreted in the urine by normal persons in 24 hours, while a larger fraction was excreted at a somewhat slower rate by individuals with myxedema. Hertz, Roberts, and Salter (13) found that less radioiodine appeared in the urine in cases of hyperthyroidism, a larger proportion being held in the thyroid gland. Again large doses of carrier favored the excretion of a larger proportion of the administered radioiodine. When $2 \mathrm{mg}$. of carrier or less was used in 11 thyrotoxic individuals, only 10 to 56 per cent of the dose could be recovered in the urine. It developed, therefore, that the proportion of a small dose or a tracer dose of iodine excreted in the urine bore an inverse relation to that taken into the thyroid gland. Several workers have used this phenomenon to study thyroid function in man in preference to direct measurements on the thyroid gland (see below).

Iodide ion can also be detected in other body secretions including saliva, tears, sweat, and milk, and it enters serous effusions and the cerebrospinal fluid (14). Radioiodine has not been used extensively to check these observations, but it can readily be detected in the saliva after it is given by mouth or by injection ( 8$)$, and it has been found to enter the cerebrospinal fluid slowly.

\section{Concentration of iodide ion by the thyroid}

Earlier work with $\mathrm{I}^{127}$ showed clearly that the thyroid is capable of accumulating iodine at a rapid rate and that this iodine is quickly bound 
to protein (15). Tracer studies with radioiodine have established that two steps are involved in this process: (1) The accumulation of iodide ion, and (2) the organic binding of iodine. It has long been known that a small amount of inorganic iodide can be detected in the normal thyroid gland and that considerable amounts may be found after iodine therapy. Large amounts of inorganic iodide are concentrated in the thyroid in hyperthyroidism after the administration of therapeutic quantities of potassium iodide (16). Lein (17) demonstrated in rabbits, given $35 \mu \mathrm{g}$. of iodide labelled with radioiodine, a prompt accumulation of inorganic iodide followed by a slow accumulation of iodine in a protein-bound form. A still clearer demonstration of the two separate mechanisms involved in iodine collection by the thyroid was given by Franklin and Chaikoff in 1944 (18). It was observed that while sulfonamides inhibited the incorporation of $\mathrm{I}^{131}$ into diiodotyrosine and thyroxine by tissue slices in vitro, these compounds did not prevent the accumulation of the $\mathrm{I}^{131}$ by the slices. McGinty (19) found in rats that, though the organic binding of iodine is completely inhibited by thiouracil feeding, the quantity of iodine in the thyroid gland can be increased by adding potassium iodide to the diet. This iodine, however, was not precipitable with protein and, therefore, presumably still in an inorganic form. It was also noted (20) that the thyroids of rats depleted of iodine by thiouracil treatment would rapidly accumulate iodine if a relatively large dose of ordinary iodide were injected; this freshly accumulated iodine was found to be unattached to protein. Further studies on the iodide ion-concentrating mechanism were greatly facilitated by the finding that it is specifically inhibited by thiocyanate.

It had been noted by Barker (21) that potassium thiocyanate could give rise to goiter and signs of myxedema in man, and it was later found to be goitrogenic in rats (22). However, thiocyanate differed from antithyroid compounds in that its goitrogenic effect could be abolished by increasing the iodide intake. Franklin, Chaikoff, and Lerner $(23,24)$, using radioiodine, and VanderLaan and Bissell (25), employing ordinary chemical methods, clearly established the effectiveness of thiocyanate in inhibiting the uptake mechanism for iodide. In a detailed study of this phenomenon VanderLaan and VanderLaan (26) established, as far as current physical and chemical methods would permit, that the iodine accumulated by the thyroid gland, when organic binding is completely inhibited by propylthiouracil, is indeed iodide ion. They showed that thyroid tissue can maintain an iodide ion concentration much higher than that of the circulating blood. This gradient, or, expressed another way, the thyroid/blood iodide ratio, is increased when the thyroid is hyperplastic. Thiocyanate inhibits this concentrating mechanism and within an hour or less after thiocyanate is given, the thyroid/ blood iodide ratio has approached $1 / 1$. It is of interest to note that VanderLaan and Vander-

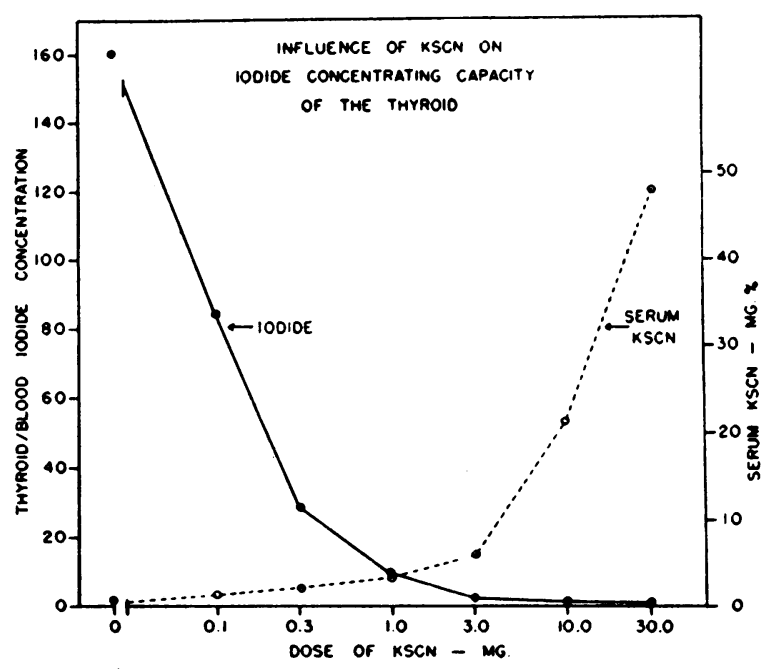

Fig. 1. The Effect in Normal Young Rats of Various Doses of Potassium Thiocyanate on the Thyrom/Blood Iodide Ratio

The animals were injected with $5 \mathrm{mg}$. of propylthiouracil to prevent organic binding of iodine and were given carrier-free radioiodine two hours, and the potassium thiocyanate one hour before being killed.

Laan found that the use of chemical methods yielded the same results as did radioiodine technics. The effect on the thyroid/blood ratio of increasing doses of $\mathrm{KSCN}$ is shown in Figure 1.

In addition to thiocyanate ion, cyanide and sulfide ions were found by Schachner, Franklin, and Chaikoff (27) to inhibit iodine uptake by thyroid slices in vitro. Neither azide, sulfanilamide (27), methylcyanide, or thiourea derivatives (23) inhibited uptake, whereas azide, thioureas, and various aminobenzene derivatives (28) 
inhibited the incorporation of the radioiodine into diiodotyrosine and thyroxine.

In the intact animal thiocyanate is the only agent which has thus far been found to inhibit the iodide-concentrating mechanism. Bromide is without effect even when given in large amounts to rat (26) or to man (29). Potassium cyanide, in the small doses tolerated, was ineffective in rats (30).

Quantitative studies in the rat showed that the thyroid/blood iodide ratio averaged 25 in the normal animal and 250 in animals whose thyroids were made hyperplastic by the administration of propylthiouracil (26). Taurog, Chaikoff, and Feller (31) also found values averaging 250 for rats with hyperplastic thyroids and noted that this did not change appreciably over the course of 24 hours following the administration of the tracer dose. Though the calculation may be somewhat in error, it is of interest to note that the values found by Franklin and Chaikoff (18) for iodide uptake in slices of normal sheep thyroid glands bathed in Ringer's solution containing sulfanilamide (cited above) permit one to estimate that the slice/fluid iodide ratio was about 40. By a different method, Wolff and Chaikoff (32) found the thyroid/blood iodide ratio of normal rats to vary between 100 and 290-a value much higher than that given by VanderLaan and VanderLaan. This possibly indicates that the thyroids were somewhat hyperplastic as a consequence of a low iodine intake; though the actual intake was not mentioned in this particular report, other papers from the same laboratory cite the value $0.1 \mu \mathrm{g}$. of iodine per gram for the diet usually employed (33). Most laboratory diets contain considerably more iodine than this and animals fed on them would have thyroids in a more nearly "resting" state. Subsequent studies in both man and rat indicate that the iodide gradient is an index of the "activity" of the thyroid. The gradient has been observed to fall rapidly after hypophysectomy and to be increased by thyrotropin (34).

Though thyroid tissue can maintain a high iodide gradient, there is a limit to the total quantity of iodide that it can contain. Appreciable additions can be made to the iodide content of the blood without altering the thyroid/blood ratio, but beyond a critical concentration the ratio progres- sively falls as the blood concentration is further increased. Taurog, Chaikoff, and Feller (31) found the ratio to be unchanged when $2 \mu \mathrm{g}$. or $100 \mu \mathrm{g}$. of iodide were given to adult rats. VanderLaan and VanderLaan (26) gave increasing doses of carrier labelled with $\mathrm{I}^{131}$ to young rats. No change in the iodide gradient resulted from doses up to $100 \mu \mathrm{g}$. of potassium iodide; $300 \mu \mathrm{g}$. reduced the ratio to half, and $1000 \mu \mathrm{g}$. to less than $1 / 10$ the control ratio. The concentrating mechanism could not be completely saturated, however, and even when $10 \mathrm{mg}$. were given, the thyroid held more iodide than an equal volume of serum.

\section{Organic binding and hormone synthesis}

Iodine compounds in the thyroid. Harington has stated that all the organic iodine in the thyroid can be accounted for in two compounds, diiodotyrosine and thyroxine, basing this conclusion on the results of a series of fractionations of the iodine compounds after alkaline hydrolysis of thyroid gland tissue in progressively stronger alkali (35). These compounds are believed to be present in the gland in peptide linkage as part of a large protein molecule, thyroglobulin, and are neither dialyzable nor directly extractable with butyl alcohol. It has recently been found that a small amount of free thyroxine can be extracted from the rat thyroid gland (36).

About 25 to 30 per cent of the organic iodine in the gland is believed to be in the thyroxine fraction, and in a study of 11 different vertebrates (37), the values were remarkably constant, ranging from 24 to 32 per cent.

If the recent claims of Fink and Fink (38) are correct, however, a radical revision of Harington's thesis would be necessary. Hydrolysis products of thyroid tissue after $I^{131}$ administration were studied by paper partition chromatography. Initially, several radioactive spots were noted which could not be attributed to the known iodine compounds of the thyroid (39), and more recently, both in man and in the rat, the radioactivity in a spot on the paper chromatogram, identified as being due to monoiodotyrosine, was found to be $1 / 3$ to $2 / 3$ as intense as that of the diiodotyrosine spot (38).

The iodination mechanism, by which the peptide-linked tyrosyl radicals are iodinated, is 
but poorly understood. It is likely that the iodide ion which has entered the gland, and presumably the follicular cell, must be oxidized to $\mathrm{I}_{2}$ or to $\mathrm{IO}^{-}$ for the iodination to proceed; an oxidative mechanism capable of effecting this step must be sought. A peroxidase enzyme would be a logical possibility, as it would meet the requirements of the high potential involved in the oxidation process. Histochemical evidence of peroxidase activity within the parenchymal cells has been offered by Dempsey (40), challenged by Glock (41), and supported by de Robertis and Grasso (42). It is an attractive hypothesis that $\mathrm{H}_{2} \mathrm{O}_{2}$ catalyzed by peroxidase converts $\mathrm{I}^{-}$to $\mathrm{I}_{2}$. But the presence of $\mathrm{H}_{2} \mathrm{O}_{2}$ has yet to be shown, and for that matter, $\mathrm{I}_{2}$ or $\mathrm{IO}^{-}$exists in the cell in theory only, or at any rate, has never been chemically identified. The actual persistence of iodine in a tissue cell in either of these forms is highly unlikely, and the transition from iodide through an oxidized form to its incorporation in the benzene ring of tyrosine may occur almost as a single step. In a study of the kinetics of the in vitro iodination of tyrosine, $\mathrm{Li}$ (43) concluded that, after entrance of the first iodine atom, the second combines immediately. If this process simulates the events in the thyroid gland, the presence of the large amounts of monoiodotyrosine reported by Fink and Fink (38) would be difficult to understand.

Conjugation. A number of facts lend support to the theory proposed by Harington and Barger (44) that diiodotyrosine is the precursor of thyroxine in the thyroid gland. Diiodotyrosine incubated at slightly alkaline $\mathrm{pH}$ will be partially converted to thyroxine (45); the iodination of casein gives a high yield of diiodotyrosine and later, after incubation, large amounts of thyroxine can be isolated $(46,47)$. Observations on the changes with time of the relative specific activities of thyroxine and diiodotyrosine in animals injected with radioactive iodine have yielded results consistent with formulae predicting the relationship of the activities of a substance and its precursor (48).

The formation of thyroxine is thought to occur as the result of the oxidative coupling of two molecules of diiodotyrosine with the elimination of one side chain. The oxidative conditions required for this coupling could potentially be provided by iodine or hypoiodite, or perhaps by what- ever mechanism produces the oxidation of iodide. It has been pointed out (49) that peroxidase could catalyze this oxidative coupling, but whether a specific enzyme is actually concerned with this step is not known.

The rate at which organic binding and coupling goes on depends on the state of activity of the gland, and is accelerated by thyrotropin (50) and exposure to cold (51), slowed by hypophysectomy $(4,52)$, and influenced by the previous iodide level (36). The rate is also affected by the iodide concentration at any moment (32), as noted below.

An interesting chemical model of the iodination process has been devised by Keston (53). $\mathrm{I}^{131}$ in iodide form added to unpasteurized milk failed to yield diiodotyrosine or thyroxine to any considerable extent until xanthine was added to the system, after which 67 per cent of the radioactive iodine could be recovered in these compounds. It is presumed that the xanthine oxidase present in milk liberated $\mathrm{H}_{2} \mathrm{O}_{2}$, which either directly, or catalyzed by the peroxidase also present in milk, oxidized the iodide to a more reactive form, which in turn iodinated tyrosyl groups. The enhancing effect of xanthine could be prevented by the addition of thiourea.

Experiments in general demonstrating that the iodination of casein (with elemental iodine) produces diiodotyrosine and thyroxine within the protein make plausible the belief that the process takes place in the thyroid gland at the level of protein molecules. Indeed, diiodotyrosine and thyroxine are formed much more rapidly in vitro when protein is iodinated than when the process is carried out with the free amino acid, tyrosine $(45,48)$.

Extra-thyroidal hormone formation has been suggested by several investigators. If radioactively labelled iodide is injected into thyroidectomized rats, small amounts of the iodine can be recovered in the various tissues of the body as diiodotyrosine and thyroxine (54). The subcutaneous injection of elemental iodine will exert thyroid hormone-like effects (55) and produce considerable iodination of tissue protein (56), but this represents a highly unphysiological situation. The metamorphosis of thyroidectomized amphibians has been found to be stimulated by iodine (57), and the metabolic rates and body weights of thyroidectomized rats have been shown to be slightly 
higher on a diet adequate in iodine than on an iodine-deficient diet (58).

The production of cretinism and myxedema by removal of the thyroid, however, would seem to be adequate evidence that if extra-thyroidal production of thyroxine occurs, the quantity falls far below the requirements of the body.

Action of antithyroid compounds. It has been well established by non-radioactive technics that antithyroid compounds of both the thiocarbonamide (thiourea derivatives, etc.) and the aminobenzene (sulfonamides, etc.) types act by inhibiting the formation of thyroid hormone. Numerous studies employing radioactive iodine have confirmed this. Both in tissue slices $(18,23,28)$ and in the intact animal $(30,31,59-62)$, these substances interfere with the organic binding of iodine, but do not inhibit the thyroid's capacity for concentrating iodide ion. When antithyroid compounds are present in effective concentrations, the incorporation of radioactive iodine into diiodotyrosine and thyroxine is prevented. The first step in hormone synthesis, the iodination of tyrosine, must, therefore, be blocked. In the face of this block, it becomes more difficult to determine whether the second step, the conversion of diiodotyrosine to thyroxine, is also affected, and in fact, it is not really known whether antithyroid compounds influence the latter process. Recently Pitt-Rivers (63) has been able to inhibit the in vitro conversion of acetyldiiodotyrosine to acetylthyroxine with a number of antithyroid compounds of both the thiocarbonamide and aminobenzene type (but with amounts of these substances which would probably represent enormous in vivo doses).

It has been observed repeatedly that following a single dose of thiouracil (or one of its relatives), or following a prolonged period of administration as well, the resumption of organic binding occurs within a matter of hours after the drug has been stopped $(64,65)$. If the administration has been continued long enough, a diminution of circulating thyroxine will occur, and an excessive output of thyrotropic hormone by the pituitary gland will have resulted $(66,67)$. The thyroid gland, under these circumstances, is found to be grossly enlarged, hyperplastic microscopically, and hyperactive as judged by the increased capacity to concentrate radioactive iodide (26). One experi- ment (68) has suggested a prolonged suppression of the capacity of the rat thyroid to bind radioiodine after a period of thiouracil administration. The turnover rate could, however, have been so fast that the single determination obtained in 48 hours would not necessarily have been conclusive.

A number of possible explanations have been suggested to account for the inhibition of the organic binding of iodine by antithyroid drugs: (1) Thiouracil immediately reduces $\mathrm{I}_{2}$ in vitro at neutral $\mathrm{pH}$, and probably, in this way, inhibits the iodination of casein (69). It could conceivably act in the thyroid either by preventing the oxidation of iodide, or by reducing the oxidation product as rapidly as it is formed. (2) Thiouracil is said to suppress the activity of the peroxidase in the follicular cell (40); and, thus, if this theory of the oxidation mechanism is correct, might act by inhibiting the catalyst of the oxidation, or by serving as a competitive substrate for peroxidase (70). (3) It has been suggested that antithyroid compounds might act by inhibiting the cytochromeoxidase system (71). The failure of antithyroid compounds to depress thyroid tissue respiration (72), however, makes this possibility remote.

It would seem unlikely, too, that cytochromeoxidase, or any enzyme which is so widely distributed in the body, should catalyze the oxidation of iodide in the thyroid gland, and not catalyze it in all other tissues as well. We do not, however, know to what factor the thyroid owes its remarkable powers for iodinating proteins. Does a specific oxidative enzyme in the thyroid cell endow it with this property, or does it rather contain only the oxidative potentialities of all cells, but gain its special property through a unique permeability to the iodide ion?

Inhibitory effect of iodide. An observation important to the understanding of the influence of iodine upon the function of the thyroid gland is the striking inhibitory effect of a high concentration of iodide upon the process of organic binding. First demonstrated in 1944 by Morton, Chaikoff, and Rosenfeld (73) for sheep tissue slices bathed with a bicarbonate-Ringer's solution containing varying concentrations of labelled iodide, this phenomenon was later more extensively investigated in intact animals by Wolff and Chaikoff (32, 74). Rats were injected with labelled iodide in doses ranging from 10 to $500 \mu \mathrm{g}$. and the amount 
of iodine organically bound calculated from the amount of radioactivity measured in the trichloracetic acid-precipitable fraction of the thyroid glands. When correlated with the plasma iodide concentration, it was clearly demonstrated that at plasma values above 20 to $35 \mu \mathrm{g}$. per cent the organic binding of iodine practically ceased (Figures $2 a$ and $2 b$ ). This inhibition could be prolonged for 40 hours from a single, large injection in nephrectomized rats (75).

Recent observations which we have made (76) suggest that, as might have been anticipated, the blocking effect of iodide correlates more directly with the concentration of the ion in the thyroid gland than with the plasma concentration. Evidence for this was obtained from the following findings: (1) The rats used in the experiments of Wolff and Chaikoff (32) maintained an exceed-


Figs. 2a and 2b. Iodide InHibition of Organic Binding

Groups of rats injected with $10 \mu \mathrm{g}$. (Figure 2a) and $200 \mathrm{\mu g}$. (Figure 2b) of iodide, respectively, as potassium iodide labelled with $\mathrm{I}^{12}$. Inhibition of organic binding (dotted line) persisted until the plasma iodide level fell to about $20.0 \mu \mathrm{g}$. per cent (from Wolff and Chaikoff [32]). ingly high thyroid-serum iodide ratio, probably due to a low dietary iodine intake. Using rats which maintained a lower ratio, we found that considerably greater amounts of iodide were required to cause inhibition of organic binding. (2) If rats injected with a blocking dose of potassium iodide were also given a dose of potassium thiocyanate, which, as indicated earlier, would lower the thyroid-serum ratio, it was found that organic binding could then occur. Under these circumstances, the thyroid iodide concentration had been lowered without changing appreciably the high plasma values.

One is tempted to apply this newer information concerning iodine influence on thyroid function to explain the well-known salutary effect of iodine in Graves' disease. In this condition, when untreated, the gland is enlarged and markedly hyperemic; the parenchymal cells are columnar and tall; the follicles are irregular with many papillary projections into the lumina, which are considerably smaller than normal. The colloid appears decreased in amount, is more liquid than the usual consistency, and the organic iodine concentration of the gland is markedly diminished. Under treatment with iodine (in amounts which are distinctly pharmacological rather than physiological), improvement in clinical signs and symptoms frequently ensues, and local changes occur in the thyroid that might reasonably be described as "involutional." The hyperemia diminishes, the follicular cells become flattened, the follicle is rounded, and its colloid content appears increased. In addition, the organic iodine concentration is greatly increased.

Wolff and Chaikoff (32) have regarded the blocking effect of iodide as a "homeostatic regulator" by means of which "the formation of toxic amounts of thyroid hormone is prevented" and believe further that this mechanism explains in part, at least, the beneficial effect of iodine in Graves' disease. To involve this mechanism alone, would, of course, leave unexplained the fact that the organic iodine content of the thyroid, both in the normal animal and in Graves' disease, increases with iodine therapy. It is interesting to note that the data presented by Chaikoff and co-workers $(32,73)$ demonstrate, though it is not pointed out by the authors, that below the iodide concentration values necessary for inhibition, the absolute 
amounts of iodine organically bound increase with increasing amounts of iodide present. This phenomenon has also been observed by us in the rat (76) and by Stanley (77) in man. This point would also be consistent with older observations $(33,78)$ that the organic iodine content of animal thyroids increases with increasing dietary iodine intake, and that intermittent iodine therapy may increase thyrotoxicity (79).

The rapid inhibition of organic binding by a large concentration of iodide is perhaps the best single piece of evidence of a direct effect of iodine upon the function of the thyroid gland. Though it may be argued that an action through the inhibition of thyrotropin has not been ruled out, the site of inhibition would, in any case, have been defined. The influence of iodine upon the size, and both gross and microscopic appearance of the thyroid treated with thiouracil $(19,80)$, and upon the gland in hyperthyroidism, further suggests a direct effect.

In the reverse situation, in which stimulation of the thyroid occurs as a result of iodine deficiency, it is difficult to know whether the lack of iodine per se acts as a stimulus to the gland, or whether this phenomenon is entirely secondary to increased pituitary stimulation.

Studies using the radioautographic technic were first made on thyroid tissue by Hamilton, Soley, and Eichorn (81) in 1940, in experiments which revealed increased radioactivity in hyperplasia and an absence of activity in the thyroid cancer tissue studied. Subsequent studies have confirmed the idea that information about the formation and storage of organic iodine compounds could be obtained by this method, and refinements in technic (82-87) have made very detailed observations possible.

By use of radioautographs, the accumulation of radioactive iodine has been shown in the stolonic septum in the ascidians, Styela and Ciona, as well as in Amphioxus (88), in the endostyle of the lamprey larva (89), in the thyroid of the parrot fish (90), and in the thyroids of $10 \mathrm{~mm}$. tadpoles (91) and 18-day-old rat embryos (92).

Leblond and Gross have studied the effects of low-iodine diet and hypophysectomy in rats in this manner (36). Whereas the autographs of rats previously maintained on $2.0 \mu \mathrm{g}$. of iodine per day showed the major concentration of radioactiv- ity in the colloid of thyroid glands removed as early as two minutes after the injection of $\mathrm{I}^{131}$, those of rats which had been maintained on a 20.0 $\mu \mathrm{g}$. per day iodine intake, showed the radioactivity chiefly within the follicular cells one hour after injection, but almost entirely in the colloid 24 hours after injection. In hypophysectomized animals, however, despite a low iodine intake, the radioactivity was largely in the follicular cells as late as 24 hours after the $\mathrm{I}^{131}$ was given. Thus, these three groups showed three distinct rates at which the processes of binding and storage were proceeding. It would seem likely from the photographs reproduced that the iodination of protein took place in the follicular cells, after which it was extruded into the lumina of the acini.

It should be remembered in interpreting these autographs that iodide ion and any dialyzable iodine compounds, would be washed out in the fixing and processing of the tissue sections as generally practiced (93), and only radioactive iodine compounds in proteins, or attached to proteins, would be influencing the autograph obtained. In this regard, the failure to obtain autographs from thiouracil-treated rats (94) could be a case in point; this occurred despite a considerable uptake of inorganic radioactive iodine by the glands.

Leblond and Gross (36) also point out that their autographs indicate that all thyroid cells are active at all times and that all the cells in any one follicle are functioning to the same degree, although there may be different degrees of activities in different follicles. In general, the center of the rat thyroid gland appears to be more active than the periphery, and the authors have also noted a correlation between activity estimations by the radioautographic technic and those based on staining reactions.

It has always been somewhat difficult to picture the mechanics by which thyroglobulin is secreted into the colloid by the thyroid cell, and then later resorbed and secreted into the blood stream. By an interesting analogy, Leblond and Gross help to make this process seem more reasonable: "It may be helpful for the understanding of the follicle function to remember its entodermal origin and to venture a comparison with the intestinal epithelium, which secretes protein (enzymes) into the lumen in a direction consistent with the histological polarity of its cells, and at the same 
time resorbs from the lumen smaller molecules resulting from digestion (amino acids Similarly, the thyroid epithelium secretes a protein (thyroglobulin) into the follicle lumen and at the same time resorbs smaller molecules, probably thyroxine itself" (36).

The function of human thyroid nodules has also been studied by radioautographs (95-97), at times with concomitant chemical and histological studies, as well as quantitative radioactivity measurements $(98,99)$. In the majority of the reported cases, the nodules have been considerably less active than the surrounding thyroid tissue, even in patients with clinical thyrotoxicosis.

\section{Hormone secretion}

That the essential molecule of thyroid hormone is thyroxine has been well established since the pioneering work of Kendall (100) and of Harington (44). Injected in pure crystalline form, it produces metabolic effects which no other known substance can, in comparable amounts, effect. But granting that thyroxine is an essential constituent of the thyroid hormone, some workers have believed that the hormone was a peptide or polypeptide containing this essential compound. Harington, by 1944, (101) was satisfied that the peptide concept was no longer necessary. The concept of thyroxine as the hormone per se has received further support from the work of Taurog and Chaikoff (102), who showed that almost all the organic iodine in plasma behaves like thyroxine in that it: (1) precipitates with the protein, (2) from which it cannot be dialyzed, (3) but from which it is readily extracted with butyl alcohol, (4) in which it remains after extraction with $4 \mathrm{~N} \mathrm{NaOH}$ -5 per cent $\mathrm{Na}_{2} \mathrm{CO}_{3}$. In addition, when a rat has labelled its plasma organic iodine from a previous injection of $\mathrm{I}^{131}$, the radioactivity follows added thyroxine carrier. The carrier thyroxine may be recrystallized to constant specific activity, and the radioactive portion resembles thyroxine in its distribution between two immiscible solvents.

Separations of plasma protein fractions have indicated that the largest portion of the proteinbound iodine is carried by albumin, while the highest concentration is in the alpha-globulin fraction, and the lowest in the gamma globulin $(102,103)$.

If we accept thyroxine as the thyroid hormone, however, a paradox results from the repeated ob- servations that the effectiveness of fed thyroid extract is greater than can be accounted for by its thyroxine content. This conclusion has been reached by experimenters using a variety of criteria for evaluating the hormonal activity, including the effect on the metabolic rate (104), the suppression of pituitary thyrotropin secretion (105), and the influence on metamorphosis of amphibia (106).

"Proteolytic enzyme." How does thyroxine, which is present in the colloid of the thyroid gland as part of the thyroglobulin molecule, reach the blood as free thyroxine? De Robertis (107) has removed colloid from the follicle lumen by microdissection and tested its proteolytic activity on the protein edestin. Proteolysis occurred with an optimal yield at about $\mathrm{pH} 4$, suggesting a cathepsin as the active enzyme in the experiment. The ubiquity and non-specificity of this type of enzyme, however, makes it a somewhat unsatisfying answer to the problem. It is, nonetheless, of considerable interest that pretreatment of the animal with thyrotropin increased the proteolytic activity and that prolonged iodine treatment, and hypophysectomy (108), decreased it. In addition, the enzyme content was found to be elevated in glands from thyrotoxic patients. One wishes that in this work the results of proteolysis without added protein had been presented, since surely there must have been present a sufficient quantity of protein in the form of the natural substrate in the colloid itself.

Protein-bound iodine of the plasma. Taurog and Chaikoff (102), as a result of their finding that the protein-bound iodine is chiefly in the form of thyroxine, have concluded that the thyroid preferentially secretes thyroxine, and that "only a small fraction of the gland's iodine leaves the gland as diiodotyrosine," although perhaps two-thirds of the organic iodine of the thyroid is in the latter form. This assumption is perhaps unnecessary, however, since it has been found repeatedly that diiodotyrosine is rapidly destroyed in the body. Thus, Leblond and Süe (4) discovered that 30 minutes after the injection of $10 \mathrm{mg}$. of radioactive diiodotyrosine into rats, 97.5 per cent of the radioactivity in the blood was in the form of iodide ion. No comparable rate of destruction of thyroxine has been demonstrated.

In this regard, it is interesting to note, too, that soon after a dose of radioactive iodide is given, 
when the radioactivity first appears in the proteinbound iodine, it is predominantly in the diiodotyrosine-like fraction; later, it is chiefly in the thyroxine-like component (50).

\section{Factors influencing the rate of hormone formation and discharge}

The rate, for a given plasma iodide level, at which thyroid hormone is formed and discharged is a function of the general level of activity of the gland, as is the iodide-concentrating power. That these processes may go on independently of each other is neatly demonstrated when, in the presence of an antithyroid drug, the power to concentrate iodide and discharge hormone is retained while hormone formation is prevented, while with thiocyanate, hormone formation and discharge can occur, although the iodide-concentrating power has been lost. Hypophysectomy greatly depresses all three processes, whereas thyrotropin raises the general level of activity of the gland. Thus, beginning eight hours after the injection of thyrotropin in man, a striking increase in the thyroid/serum iodide ratio occurs, as demonstrated by simultane-



Fig. 3. Three Successive Tracer Studies with Radiolodine in a Normal Human Subject Who Had Taken 5 Grains of Thyroid DaIly for Several Months

A single injection of $15 \mathrm{mg}$. of thyrotropin was given $4 \frac{1}{2}$ hours before the first dose of radioiodine; its effect was noticeable toward the end of the first day and was maximal during the first four hours of the second day; the thyroid had returned to its suppressed state by the fourth day (redrawn from Stanley and Astwood [109]).

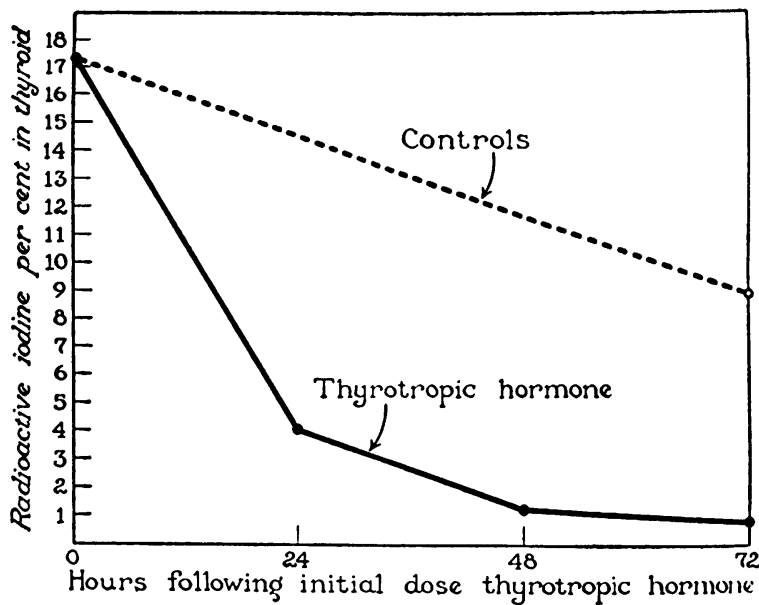

Fig. 4. Influence of Thyrotropic Hormone on the Rate of Discharge of Organically Bound RadioIOdINE BY THE ChICK ThyroId

(From Keating, Rawson, Peacock, and Evans [110]).

ous measurements of radioactivity in the antithyroid-blocked gland and the serum (109). The rate at which radioactive iodine is incorporated into thyroid organic iodine is markedly hastened by thyrotropin $(4,50)$ (Figure 3 ), as is the rate at which radioactivity appears in the proteinbound iodine (50). It is well known that injections of thyrotropin rapidly deplete the organic iodine content of the thyroid of animals, indicating that, under the conditions of the experiments, at least, the rate of iodine binding does not initially keep up with the rapid rate of discharge. Using radioiodine, Keating, Rawson, Peacock, and Evans (110) found that thyrotropin accelerated the loss of protein-bound iodine from the thyroid gland (Figure 4). Other changes after thyrotropin, such as the liquefaction of the colloid and the reduction in colloid in the follicles, are consistent with the concept of increased proteolytic activity.

Many other factors undoubtedly influence the level of activity of the gland, including the dietary iodine intake and environmental temperature. Leblond et al. (51) found that rats exposed to an environment at $0^{\circ} \mathrm{C}$. have a higher radioiodine uptake than rats at $22^{\circ}$ to $26^{\circ} \mathrm{C}$. (control $\mathrm{T}^{\circ}$ ), and by the goiter-prevention method (111), it can be shown that a greater amount of administered thyroxine is required in a cold, than in a warm environment. 


\section{The fate of thyroxine in the body}

When radioactive thyroxine, labelled in the $3^{\prime}, 5^{\prime}$ positions, is injected into rabbits, very little is found in the thyroid, or in the foetus of a pregnant animal, but a considerable amount rapidly appears in the urine, and the iodine content in the bile is $\mathbf{5 0}$ times as great as after an equal amount of iodine as iodide ion (112). dl-Thyroxine, labelled as in the preceding experiment, has been injected into rats and its distribution at two and 24 hours studied in more than 40 organs and tissues (113). When the dose was $0.8 \mathrm{mg}$., approximately 25 per cent of the administered thyroxine was destroyed in two hours and 50 per cent in 24 hours, by which time 80 to 95 per cent of the iodine content had been eliminated from the body. The major route of elimination was via the liver and bile, and within 24 hours, 80 per cent of the injected dose was recovered in the feces, to a large extent as thyroxine. A part of this thyroxine came from direct excretion by the gastrointestinal mucosa. About 11 per cent of the iodine was recovered in the urine after this interval as inorganic iodine, while the organic iodine content of the urine was very small. Within two hours of the injection, 50 per cent was found in the gastrointestinal tract (including liver and pancreas), and not more than 2 per cent could be recovered in the entire circulating plasma volume.

These results on the fate of thyroxine in the body apply to large, unphysiological amounts, and much less is known about the normal course of events. After thyroidectomy in rats, it takes three days for the protein-bound iodine to fall to one-third of its initial level (114), suggesting a much slower rate of loss of thyroxine at physiological levels. However, in an experiment in which rat plasma containing labelled proteinbound iodine was injected intravenously into dogs, it was calculated that the protein-bound iodine was completely replaced every four to seven and one-half hours (115).

\section{Radioiodine in clinical investigation and diagnosis}

Investigations on animals have been facilitated by the use of radioiodine and many studies which could be done with ordinary iodine were rendered much less laborious with tracer technics. In clinical studies, however, tracer methods have made it possible to carry out investigations on thyroid function of a kind which was not possible by other methods. Several different technics have been evolved to estimate the rate of iodine utilization by the thyroid gland, and these have aided in the diagnosis of myxedema and hyperthyroidism, and have furthered the study of simple goiter. These methods have also been applied to the study of factors which influence thyroid function in man such as antithyroid compounds, thiocyanate ion, iodide ion, thyroid administration, thyrotropin, and the ingestion of certain foods.

The urinary excretion of a tracer dose has been used as an indirect measure of thyroid activity by making use of the fact that a proportion of the tracer dose which does not appear in the urine is retained in the thyroid gland. Hamilton and Soley (12), and later Hertz, Roberts, and Salter (13), showed that the urinary excretion of radioiodine had diagnostic value. Rawson et al. (116) have shown, by this method, that thiouracil treatment permitted the excretion of the major portion of a tracer dose in the urine, while thyrotoxic patients and one patient with a large hyperplastic non-toxic goiter excreted less than one quarter of the administered radioiodine during 48 hours. Measurements on urinary excretion have also proved useful in determining the amount retained when large doses of radioiodine are used in the investigation and treatment of thyroid tumors (117-119) and in the treatment of hyperthyroidism with radioiodine $(120,121)$.

Despite the difficulties involved, several observers have found the urinary excretion method of considerable value in the diagnosis of hyperand hypothyroidism. Skanse (122) measured the amount of radioiodine excreted in the urine during the 48 hours after the administration of 100 $\mu \mathrm{g}$. of iodide labelled with $\mathrm{I}^{131}$ and found that hyperthyroid patients uniformly excreted less than normal individuals. Oshry and Schmidt (123) measured the total quantity of radioiodine excreted during the first 24 hours after a tracer dose. The values abserved are shown in Table $\mathrm{I}$.

A detailed study of the rate of urinary excretion of radioiodine by Keating, Power, Berkson, and Haines (124) has permitted an accurate in- 
TABLE I

\begin{tabular}{|c|c|c|c|c|}
\hline & \multicolumn{2}{|c|}{ Skanse (122) } & \multicolumn{2}{|c|}{$\begin{array}{l}\text { Oshry and Schmidt } \\
(123)\end{array}$} \\
\hline & $\begin{array}{l}\text { No. of } \\
\text { cases }\end{array}$ & $\begin{array}{l}\text { Range of } \\
\text { radioiodine } \\
\text { excretion } \\
48 \text { hours }\end{array}$ & $\begin{array}{l}\text { No. of } \\
\text { cases }\end{array}$ & $\begin{array}{l}\text { Range of } \\
\text { radioiodine } \\
\text { excretion } \\
24 \text { hours }\end{array}$ \\
\hline $\begin{array}{l}\text { Normal } \\
\text { Myxedema } \\
\text { Hyperthyroid }\end{array}$ & $\begin{array}{r}15 \\
6 \\
25\end{array}$ & $\begin{array}{r}52.7 \text { to } 84.1 \\
72.4 \text { to } 91.7 \\
6.2 \text { to } 32.3\end{array}$ & $\begin{array}{l}23 \\
10 \\
34\end{array}$ & $\begin{array}{r}42 \text { to } 80 \\
48 \text { to } 93 \\
5 \text { to } 43\end{array}$ \\
\hline
\end{tabular}

terpretation of the findings obtained by this method; they have shown that, as the blood is cleared of radioiodine by its excretion in the urine and its incorporation into the thyroid gland, the quantity excreted in the urine progressively declines. Consequently, from the quantities excreted in the urine, measured at frequent intervals, the rate of disappearance of radioiodine from the blood can be calculated.

Keating et al. made use of the expression,

$$
Q=Q_{f}\left(1-e^{-r t}\right) \text {, }
$$

where $Q$ is the fraction of the tracer dose excreted in the urine in time $t ; Q_{t}$ the total quantity to be excreted; and $r$, a constant defining the rate of disappearance of radioiodine from the blood. The disappearance rate, $r$, was computed, then, from the formula,

$$
r=\frac{\log \left(Q_{t}-Q\right)}{t \log e}
$$

or as the slope of the straight line plot of $\log \left(Q_{\mathbb{R}}-Q\right)$ against t. As $Q_{r}$ is the fraction to appear in the urine, $1-Q_{1}$ would be the fraction retained in the body. Therefore, the urinary excretion rate becomes:

$$
Q_{f} \times r
$$

and the rate of disappearance elsewhere, the "collection rate" is :

$$
\left(1-Q_{f}\right) \times r \text {. }
$$

This last expression is an index of the rate of incorporation of the tracer dose into the thyroid gland (Figure 5).

The validity of these concepts was established by similar calculations made by estimating the blood disappearance rate on the basis of actual measurements on blood samples, and by calculations using measurements of the accumulation of radioiodine by the thyroid gland. It was even possible to use the decreasing radioactivity of the thigh as a measure of the disappearance rate.

In individuals with thyrotoxicosis the disappearance rate may be extremely rapid and these calculations then do rot so nicely follow mathematical prediction. Presumably, at least two additional factors complicate the picture here: (1) The thyroid collection rate is not uniform because it is the resultant of two rates, the rate of establishment of iodide ion equilibrium and the rate of organic binding, and (2) the significant rate of excretion of iodine-containing compounds by the thyroid gland.

A certain proportion of the radioiodine which fails to appear in the urine cannot be accounted for by the amount which is measured in the thyroid gland. In earlier experiments this "unaccounted for" fraction was very large (13), due probably to technical difficulties of measurement. Even with refined technics, however, some 10 to 20 per cent of the dose is not accounted for (125). It would be expected that a certain small fraction of the administered dose would be contained in the intestinal tract, and some of this might be lost in the stools. It is possible that a small fraction would be excreted by the sweat glands. The observations of Keating et al. (124) cited above show that when the turnover of iodine by the thyroid is very rapid, a slow excretion of radioiodine continues for some days after the tracer dose is given. Consequently, another fraction of the "unaccounted for" radioiodine could be that which has been secreted by the thyroid in the form of thyroxine and temporarily stored in body tissue. Direct measurements on the quantity of radioiodine in the thyroid gland are probably more accurate than estimates based on urinary excretion and are far simpler to carry out. Direct measurements of the collection of iodine by the thyroid gland, using appropriate apparatus, is a more convenient and more versatile method for thyroid studies in man. Methods and detecting devices are constantly being improved, but as yet strictly precise, absolute measurements are not possible. However, for most purposes any one of several currently used technics is satisfactory (125-128), and the method of choice depends upon the nature of the study. When it is desired to determine only the total quantity of radioiodine accumulated, a single measurement at 24 to 48 hours after the tracer dose is sufficient; when more detailed information is desired, measurements can be made at frequent intervals. During the early minutes or hours after a tracer dose is given, the radioiodine is distributed throughout the body and provides a diffuse radiation which complicates the measurements on the thyroid gland. The greater the distance between the detector and the gland, the greater is the difficulty of shielding off the radiation from the rest of the body. When this error 
is minimized by placing the detector as close to the thyroid as possible, errors due to positioning and to size, location, and shape of the thyroid gland become maximal. These considerations imply that when absolute values are desired, measurements must be made at a distance and preferably at a time when the body in general contains little radioiodine. When the observation of rapid changes, occurring soon after the tracer is given, is more important than information on the number of microcuries in the gland, it may be necessary to sacrifice the added accuracy of distance in favor of the simpler shielding problem of closer placement.

Curves depicting the collection of radioiodine by the thyroid gland resemble those obtained by Keating et al. (124) for cumulative urinary excretion. The course of uptake is apparently complex, and no simple mathematical expression is
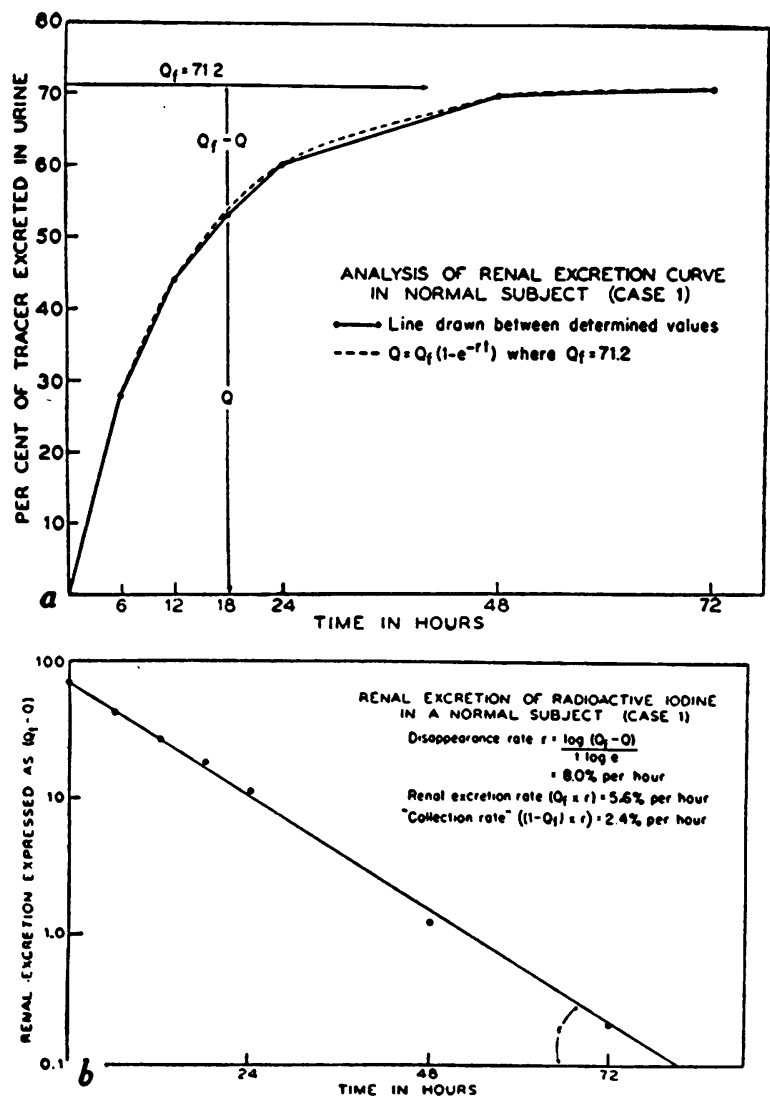

Fig. 5. Determination of Rate of Disappearance of Radioiodine from the Blood ( $r$ ) by Analysis of the Renal Excretion Curve

(From Keating, Power, Berkson, and Haines [124]).

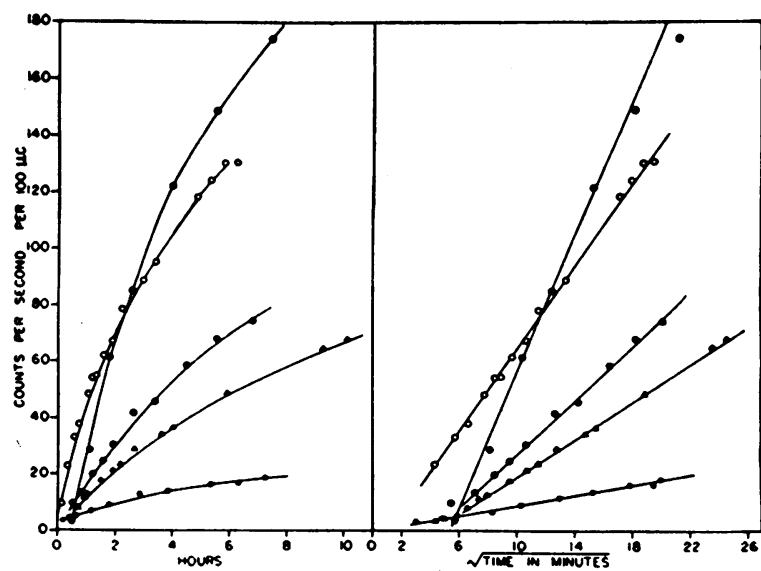

Fig. 6. The Course of Radiolodine Accumulation in the Thyroid Glands of Three Normal and Two THYROTOXIC INDIVIDUALS

The figure on the right illustrates the approximately linear relationship when the abscissa is a square root scale.

applicable to all individuals. The formulation of Keating et al. provides an approximate description of the pattern seen in most normal persons. In other normal persons and in many abnormal individuals the relationship fails to hold. Another approximation (65) which describes the curve of collection during the first part of its length is the simple relationship

$$
Q=\mathrm{G} \sqrt{\mathrm{T}},
$$

where $Q$ is the quantity of radioiodine in the thyroid gland at time $T$; and $G$ is a rate constant which serves as an index of the rate of uptake. This expression describes the course of uptake quite accurately in normal persons for the first eight or ten hours after the tracer is given. In hyperthyroidism and in certain instances of goiter, when the collection is rapid, deviation from the parabolic curve occurs sooner, and in some instances the curve of uptake bears little resemblance to a parabola. On the other hand, when the rate of collection is slow, the curve of uptake follows the parabolic curve quite closely for as long as 24 hours (Figure 6).

This method of expressing the rate of accumulation suffers the disadvantages of: (1) Incomplete description of the whole process, (2) marked and early deviations in certain cases, and, (3) obscure mathematical significance. It has the advantage, however, of providing a measurement 
of rate within an hour or two of the beginning of the tracer study, and it is the only satisfactory method thus far devised which makes it possible to define the accumulation rate early enough to allow studies on extraneous factors which induce rapid changes in the rate of accumulation.

The rate as determined in this way is not proportional to the total accumulation and is less suitable than the latter as a diagnostic method for hyperthyroidism. Either method is suitable when the diagnosis of myxedema is in question. Neither of these methods is entirely reliable for diagnosis, however, as the range of variation in normal individuals overlaps at either end with myxedema and thyrotoxicosis. Erroneously low accumulation rates and low total uptakes follow iodine or thyroid medication, the administration of compounds used for cholecystography, and the installation of iodized oils into the lungs, subarachnoid space, or other body cavities. Rapid rates and large total uptakes within the hyperthyroid range are sometimes seen in apparently normal persons and in some instances of non-toxic goiter. Despite these limitations, the two methods are valuable and frequently provide strong evidence for or against a diagnosis of myxedema or hyperthyroidism.

Werner, Quimby, and Schmidt (129) have extensively investigated the total collection of iodine by the thyroid by direct measurements 24 hours after the tracer dose. The data are shown in Table II from which it may be seen that little overlap between the normal values and those of hyperthyroids was encountered.

Iodide ion. Radioiodine, used in conjunction with antithyroid compounds, has made it possible to study the iodide ion concentration by the thyroid gland in human beings and the effects thereon of thiocyanate (29). In man, thyroid hyperplasia, as seen in hyperthyroidism and in certain non-toxic goiters of recent development, is associated with a greatly increased capacity of the gland to hold iodide ion and quantitative measurements of this phenomenon have diagnostic value. Potassium thiocyanate given orally in doses of about 1 gram greatly interferes with the ion-concentrating mechanism and virtually all $\mathrm{I}^{131}$ present in the gland in ionic form is lost within an hour.

The organic binding of iodine by the thyroid can be completely or very nearly completely inhibited by the administration of effective doses of an antithyroid compound. Mercaptoimidazole has been used for this purpose because of its high activity in man and its prolonged action, and more recently 1-methyl-2-mercaptoimidazole has proved to be convenient because of the small size of the doses that need be given (130). When radioiodine is administered after the thyroid is fully under the influence of such compounds, it serves to label the iodide ion of the body fluids and the thyroid gland. As far as one can tell, this iodide ion does not enter into any chemical reaction in the body and interpretations are, there-

TABLE II *

\begin{tabular}{|c|c|c|c|c|c|c|c|c|c|c|c|}
\hline \multicolumn{2}{|c|}{$\begin{array}{l}\text { Radioiodine } \\
\text { accumulation } \\
\text { in } 24 \text { hours }\end{array}$} & $\begin{array}{l}\text { Normal } \\
\text { subjects }\end{array}$ & $\begin{array}{c}\text { Hyperthy- } \\
\text { roidism }\end{array}$ & $\underset{\text { goiter }}{\text { Nontoxic }}$ & $\begin{array}{c}\text { Malignant } \\
\text { exoph- } \\
\text { thalmos }\end{array}$ & $\begin{array}{c}\text { Eosino- } \\
\text { phile } \\
\text { adenoma }\end{array}$ & $\begin{array}{c}\text { Chromo- } \\
\text { phobe } \\
\text { adenoma }\end{array}$ & $\begin{array}{c}\text { Addison's } \\
\text { disease }\end{array}$ & $\begin{array}{l}\text { Cushing's } \\
\text { syndrome }\end{array}$ & Obesity & $\begin{array}{c}\text { Anorexia } \\
\text { nervosa }\end{array}$ \\
\hline $\begin{array}{l}\mathbf{H} \\
\mathbf{I} \\
\mathbf{G} \\
\mathbf{H}\end{array}$ & $\begin{array}{l}\text { per cent } \\
50- \\
40-49 \\
35-39\end{array}$ & $\begin{array}{l}0 \\
2 \\
4\end{array}$ & $\begin{array}{r}57 \\
29 \\
5\end{array}$ & $\begin{array}{l}0 \\
2 \\
2\end{array}$ & $\begin{array}{l}3 \\
1 \\
0\end{array}$ & $\begin{array}{l}0 \\
2 \\
1\end{array}$ & $\begin{array}{l}\mathbf{0} \\
\mathbf{0} \\
\mathbf{0}\end{array}$ & $\begin{array}{l}0 \\
0 \\
0\end{array}$ & $\begin{array}{l}0 \\
0 \\
0\end{array}$ & $\begin{array}{l}0 \\
0 \\
0\end{array}$ & 1 \\
\hline $\begin{array}{l}\mathbf{N} \\
\mathbf{O} \\
\mathrm{R} \\
\mathbf{M} \\
\mathrm{A} \\
\mathbf{L}\end{array}$ & $\begin{array}{l}30-34 \\
20-29 \\
10-19\end{array}$ & $\begin{array}{r}8 \\
24 \\
18\end{array}$ & $\begin{array}{l}2 \\
2 \\
2\end{array}$ & $\begin{array}{l}2 \\
3 \\
1\end{array}$ & $\begin{array}{l}0 \\
3 \\
1\end{array}$ & $\begin{array}{l}1 \\
2 \\
4\end{array}$ & $\begin{array}{l}0 \\
1 \\
5\end{array}$ & $\begin{array}{l}1 \\
1 \\
3\end{array}$ & $\begin{array}{l}0 \\
0 \\
1\end{array}$ & $\begin{array}{l}3 \\
3 \\
1\end{array}$ & $\begin{array}{l}1 \\
1 \\
3\end{array}$ \\
\hline $\begin{array}{l}\text { L } \\
\mathbf{O} \\
\text { W }\end{array}$ & $0-9$ & 1 & 0 & 1 & 0 & 0 & 3 & 0 & 1 & 1 & 0 \\
\hline
\end{tabular}

- Compiled from data of Werner, Quimby, and Schmidt (129). 
fore, greatly simplified. Within an hour or two after the tracer dose is given, the radioiodine seems to have distributed itself throughout the body's iodide and this state of equilibrium is maintained for as long as detectable quantities of radioiodine remain in the body. The ion is lost from the body almost exclusively through the urine, and, as a certain fraction of what remains is lost during each succeeding interval of time, the rate of loss is an exponential function. Thus, if one plots the log of the blood concentration against elapsed time, a straight line results. Now, as mentioned above, the thyroid gland can steadily maintain a concentration gradient of iodide ion, and equilibrium conditions here are also quickly established. It follows, therefore, that the maximal thyroid content of radioiodide is to be observed within an hour or two of the tracer dose; thereafter the radioiodide in the thyroid gland declines slowly in a regular logarithmic fashion and becomes undetectable in two to four days. Calculations can be made in man of the thyroid/blood iodide ratio, and, while these are subject to considerable error from patient to patient, the calculated ratio remains remarkably constant throughout the course of a tracer study on any individual. The decline in the thyroid radioiodide parallels closely the decline in blood radioiodine concentration, so that the ratio remains the same for as long as it can be measured, provided, of course, that sufficient antithyroid compound be given to prevent any change in the chemical state of the iodine.

In the diagnosis of hyperthyroidism, tracer studies of the thyroid iodide content have proved to be more reliable than measurements of the total iodine uptake. There is a greater difference between the hyperthyroid gland and the normal gland, and, with the exception of certain hyperplastic non-toxic goiters, there appears to be no overlap of the ranges of normal and hyperthyroid persons. Furthermore, as might have been predicted from the animal experiments cited above, extraneous ordinary iodide has much less influence on the iodide-concentrating mechanism, and doses of potassium iodide up to $10 \mathrm{mg}$. or more can be given without altering the thyroid radioiodide. The large collection of iodide ion exhibited by the thyroid in hyperthyroidism and by certain non-toxic goiters can be reproduced in normal individuals by the injection of a single, large dose of thyrotropin (109).



FIG. 7

In the presence of a large carrier dose, the curve of radioiodine uptake and discharge represents largely iodide ion. Thus, the radioactivity in the thyroid may be discharged with thiocyanate (dotted line graph). The carrier doses in the above cases are in the range which inhibits organic binding, but are well below the amount required to depress the thyroid/serum iodide ratio. 
If further study confirms the finding that a sudden increase in blood iodide inhibits the organic binding of iodine, another and perhaps better method will be provided for measuring the thyroid iodide for diagnostic purposes. In this instance an appropriate dose of carrier iodine would replace the antithyroid compound. For some hours after the administration of $10 \mathrm{mg}$. or more of labelled potassium iodide, the quantity of radioiodine fixed in the thyroid is very small. However, within an hour or two of such a dose there is a maximal accumulation of iodine which presumably is free iodide ion, as it is readily discharged by a dose of potassium thiocyanate (Figure 7). The quantity of iodide accumulated under these conditions is independent of the dose of carrier iodide within wide limits. One could, therefore, use a constant dose of carrier with the diagnostic radioiodine in a quantity large enough to reduce the proportion that will be organically bound to a very small value and yet not so large as to impose a limit to the concentrating mechanism. Measurements need only to be made until the early maximum is reached, a period of one to three hours. This technic would be essentially that which Hamilton and Soley used in their first experiments in 1940 (126). The method would have the advantage of simplicity and the time required to carry out the test would be reduced to a minimum. One might anticipate that, though a small fraction of the iodide would be bound, this would be so small in comparison to the quantity concentrated as iodide that it would not seriously interfere with the test.

Antithyroid compounds can readily be studied in normal human beings by making use of the $Q=G \sqrt{T}$ relationship (65). Frequent determinations over one to two hours following the oral administration of a tracer dose permits one to calculate the value of $G$ and to plot the course of uptake with some assurance. A test dose of compound is then given and a significant deviation from the predicted course of events can with reasonable certainty be ascribed to the antithyroid compound. This method has given useful information on the relative antithyroid activities of several compounds and has led to the development of agents which are many times more effective in man than is thiouracil. Some information can be gained, in this way, on the duration of action as well as on the minimal effective dose.

Foods of possible or potential influence on thyroid function have also been tested in this way (131). The technic used was the same as that described above, except that a full meal of a single food was given instead of a dose of antithyroid compound. A number of foods, especially vegetables, were found to have slight effects on the rate of radioiodine collection by the thyroid gland, and some, such as turnips, were strongly inhibitory. These studies led to the isolation and characterization of an active antithyroid compound in turnip, a substance which was found to be widely distributed among the plants of the brassica genus (132).

Thyroid administration has been observed to have no significant effect upon the accumulation of radioiodine by the thyroid gland during the first ten hours following a single dose. A large dose was found to be definitely inhibitory by 24 hours (133), however, and prolonged treatment in normal individuals virtually abolished the uptake of radioiodine $(109,129)$.

Thyrotropin was likewise without detectable effect until some eight to 14 hours had elapsed after a single injection. Then a marked increase in the rate of uptake was noted and this lasted for several days (Figure 3 ). The negligible uptake resulting from prolonged administration of thyroid could be restored to normal by an injection of thyrotropin (109).

Means (134), writing in 1948, has stated, in reference to the use of radioactive iodine in the field of research, that he had "at the time of its introduction, predicted that its usefulness in this field would be greater than in that of therapeutics. Now, after an elapse of ten years, it can be said that the usefulness of radioactive iodine in thyroid research has been firmly established."

\section{BIBLIOGRAPHY}

1. Fermi, E., Radioactivity induced by neutron bombardment. Nature, 1934, 133, 757.

2. Hertz, S., Roberts, A., and Evans, R. D., Radioactive iodine as an indicator in the study of thyroid physiology. Proc. Soc. Exper. Biol. \& Med., 1938, 38, 510

3. Miller, W. H., Anderson, G. W., Madison, R. K., and Salley, D. J., Exchange reactions of diiodotyrosine. Science, 1944, 100, 340. 
4. Leblond, C. P., and Süe, P., Iodine fixation in the thyroid as influenced by the hypophysis and other factors. Am. J. Physiol., 1941, 134, 549.

5. Morton, M. E., and Chaikoff, I. L., The formation in vitro of thyroxine and diiodotyrosine by thyroid tissue with radioactive iodine as indicator. J. Biol. Chem., 1943, 147, 1.

6. Wallace, G. B., and Brodie, B. B., The distribution of administered iodide and thiocyanate in comparison with chloride and their relation to body fluids. J. Pharmacol. \& Exper. Therap., 1937, 61, 397.

7. Davenport, H. W., The secretion of iodide by the gastric mucosa. Gastroenterology, 1943, 1, 1055.

8. Schiff, L., Stevens, C. D., Molle, W. E., Steinberg, H., Kumpe, C. W., and Stewart, P., Gastric (and salivary) excretion of radioiodine in man. J. Nat. Cancer Inst., 1947, 7, 349.

9. Marinelli, L. D., and Hill, R. F., Radioiodine. Studies on dosage in cancer therapy. Brookhaven Conf. Rep., July 1948, BNL-C-5, 98.

10. Trunnell, J. B., $\mathrm{I}^{181}$ as a therapeutic agent in cancer of the thyroid. Brookhaven Conf. Rep., July 1948, BNL-C-5, 112.

11. Riggs, D. S., Renal clearance of iodide in the dog. Federation Proc., 1949, 8, 328.

12. Hamilton, J. G., and Soley, M. H., Studies in iodine metabolism by the use of a new radioactive isotope of iodine. Am. J. Physiol., 1939, 127, 557.

13. Hertz, S., Roberts, A., and Salter, W. T., Radioactive iodine as an indicator in thyroid physiology. IV. The metabolism of iodine in Graves' disease. J. Clin. Invest., 1942, 21, 25.

14. Elmer, A. W., Iodine Metabolism and Thyroid Function. Oxford U. Press, London, 1938.

15. Marine, D., and Rogoff, J. M., The absorption of potassium iodide by the thyroid gland in vivo following its intravenous injection in constant amounts. J. Pharmacol. \& Exper. Therap., 1916, 8, 439.

16. Gutman, A. B., Benedict, E. M., Baxter, B., and Palmer, W. W., The effect of administration of iodine on the total iodine inorganic iodine and thyroxine content of the pathological thyroid gland. J. Biol. Chem., 1932, 97, 303.

17. Lein, A., Studies on the fixation of radioactive iodine by the rabbit thyroid. Endocrinology, 1943, 32, 429.

18. Franklin, A. L., and Chaikoff, I. L., The effect of sulfonamides on the conversion in vitro of inorganic iodide to thyroxine and diiodotyrosine by thyroid tissue with radioactive iodine as indicator. J. Biol. Chem., 1944, 152, 295.

19. McGinty, D. A., Iodine absorption and utilization under the influence of certain goitrogens. Ann. New York Acad. Sc., 1949, 50, 403.

20. Astwood, E. B., Chemotherapy of hyperthyroidism. Harvey Lect., 1944, 40, 195.

21. Barker, M. H., The blood cyanates in the treatment of hypertension, J. A. M. A., 1936, 106, 762.
22. Astwood, E. B., The chemical nature of compounds which inhibit the function of the thyroid gland. J. Pharmacol. \& Exper. Therap., 1943, 78, 79.

23. Franklin, A. L., Chaikoff, I. L., and Lerner, S. R., The influence of goitrogenic substances on the conversion in vitro of inorganic iodide to thyroxine and diiodotyrosine by thyroid tissue with radioactive iodine as indicator. J. Biol. Chem., 1944, 153, 151 .

24. Wolff, J., Chaikoff, I. L., Taurog, A., and Rubin, L., The disturbance in iodine metabolism produced by thiocyanate: the mechanism of its goitrogenic action with radioactive iodine as indicator. Endocrinology, 1946, 39, 140.

25. VanderLaan, W. P., and Bissell, A., Effects of propylthiouracil and of potassium thiocyanate on the uptake of iodine by the thyroid gland of the rat. Endocrinology, 1946, 39, 157.

26. VanderLaan, J. E., and VanderLaan, W. P., The iodide-concentrating mechanism of the rat thyroid and its inhibition by thiocyanate. Endocrinology, 1947, 40, 403.

27. Schachner, H., Franklin, A. L., and Chaikoff, I. L., On the in vitro accumulation of inorganic iodide by surviving thyroid tissue with radioactive iodine as indicator. Endocrinology, 1944, 34, 159.

28. Taurog, A., Chaikoff, I. L., and Franklin, A. L., The structural specificity of sulfanilamide-like compounds as inhibitors of the in vitro conversion of inorganic iodide to thyroxine and diiodotyrosine by thyroid tissue. J. Biol. Chem., 1945, 161, 537.

29. Stanley, M. M., and Astwood, E. B., The accumulation of radioactive iodide by the thyroid gland in normal and thyrotoxic subjects and the effect of thiocyanate on its discharge. Endocrinology, 1948, 42, 107.

30. VanderLaan, J. E., and VanderLaan, W. P., Personal communication. 1947.

31. Taurog, A., Chaikoff, I. L., and Feller, D. D., The mechanism of iodine concentration by the thyroid gland: its non-organic iodine-binding capacity in the normal and propylthiouracil-treated rat. J. Biol. Chem., 1947, 171, 189.

32. Wolff, J., and Chaikoff, I. L., Plasma inorganic iodide as a homeostatic regulator of thyroid function. J. Biol. Chem., 1948, 174, 555.

33. Taurog, A., and Chaikoff, I. L., The relation of the thyroxine content of the thyroid gland and of the level of protein-bound iodine to iodine intake. J. Biol. Chem., 1946, 165, 217.

34. Greer, M., and VanderLaan, W. P., The relationship of the hypophysis to the iodine metabolism of the thyroid gland of the rat. (To be published.)

35. Harington, C. R., Newer knowledge of the biochemistry of the thyroid gland. J. Chem. Soc. (London), 1944, 193.

36. Leblond, C. P., and Gross, J., Thyroglobulin formation in the thyroid follicle visualized by the "coated autograph" technique. Endocrinology, 1948, 43, 306. 
37. Kolff, J., and Chaikoff, I. L., The relation of thyroxine to total iodine in the thyroid gland. Endocrinology, 1947, 41, 295.

38. Fink, K., and Fink, R. M., The formation of monoiodotyrosine from radioiodine in the thyroid of rat and man. Science, 1948, 108, 358.

39. Fink, R. M., Dent, C. E., and Fink, K., Application of filter paper partition chromatography to radioactive tracer studies. Nature, 1947, 160, 801.

40. Dempsey, E. W., Fluorescent and histochemical reactions in the rat thyroid gland at different states of physiological activity. Endocrinology, 1944, 34, 27.

41. Glock, G. E., Peroxidase activity of the thyroid. Nature, 1944, 154, 460.

42. de Robertis, E., and Grasso, R., Peroxidase activity of the thyroid gland under normal and experimental conditions. Endocrinology, 1946, 38, 137.

43. Li, C. H., Kinetics and mechanism of 2-6-diiodotyrosine formation. J. Am. Chem. Soc., 1942, 64, 1147.

44. Harington, C. R., and Barger, G., Chemistry of thyroxine; constitution and synthesis of thyroxine. Biochem. J., 1927, 21, 169.

45. von Mutzenbecher, $P$., Uber die Bildung von Thyroxin aus Dijodtyrosin. Ztschr. f. physiol. Chem., 1939, 126, 253.

46. Ludwig, W., and von Mutzenbecher, P., Die darstellung von Thyroxin, Monojodtyrosin und Dijodtyrosin aus jodiertem Eiweiss. Ztschr. f. physiol. Chem., 1939, 258, 195.

47. Reineke, E. P., and Turner, C. W., The effect of manganese compounds and certain other factors on the formation of thyroxine in iodinated casein. J. Biol. Chem., 1945, 161, 613.

48. Taurog, A., and Chaikoff, I. L., The metabolic interrelations of thyroxine and diiodotyrosine in the thyroid gland, as shown by a study of their specific activity-time relations in rats injected with radioactive iodine. J. Biol. Chem., 1947, 169, 49.

49. Westerfeld, W. W., and Lowe, C., The oxidation of p-cresol by peroxidase. J. Biol. Chem., 1942, 145, 463.

50. Morton, M. E., Perlman, I., and Chaikoff, I. L., Radioactive iodine as indicator of metabolism of iodine. III. The effect of thyrotropic hormone on the turnover of thyroxine and diiodotyrosine in the thyroid gland and plasma. J. Biol. Chem., 1941, 140, 603.

51. Leblond, C. P., Gross, J., Peacock, W., and Evans, R. D., Metabolism of radioiodine in the thyroids of rats exposed to high or low temperatures. Am. J. Physiol., 1944, 140, 671.

52. Morton, M. E., Perlman, I., Anderson, E., and Chaikoff, I. L., Radioactive iodine as indicator of metabolism of iodine. V. The effects of hypophysectomy on the distribution of labeled thyroxine and diiodotyrosine in thyroid gland and plasma. Endocrinology, 1942, 30, 495.

53. Keston, A. S., The Schardinger enzyme in biological iodinations. J. Biol. Chem., 1944, 153, 335.
54. Morton, M. E., Chaikoff, I. L., Reinhardt, W. O., and Anderson, E., Radioactive iodine as an indicator of the metabolism of iodine. VI. The formation of thyroxine and diiodotyrosine by the completely thyroidectomized animál. J. Biol. Chem., 1943, 147, 757.

55. Dvoskin, S., The thyroxine-like action of elemental iodine in the rat and chick. Endocrinology, 1947, 40, 334.

56. Barker, S. B., and Lipner, H. J., In vivo iodination of tissue protein following injection of elemental iodine $\left(I^{12 r}\right)$. Science, 1948, 108, 539.

57. Swingle, W. W., Iodin as the active principle of the thyroid gland. Endocrinology, 1918, 2, 283.

58. Chapman, A., Extrathyroidal iodine metabolism. Endocrinology, 1941, 29, 686.

59. Keston, A. S., Goldsmith, E. D., Gordon, A. S., and Charipper, H. A., The effect of thiourea upon the metabolism of iodine by rat thyroid. J. Biol. Chem., 1944, 152, 241.

60. Rawson, R. W., McGinty, D. A., and Peacock, W., The comparative effect of various goitrogenic agents on the collection of radioactive iodine by the thyroid in rats and chicks. Endocrinology, 1946, 39, 78.

61. Rawson, R. W., McGinty, D. A., Peacock, W., Merrill, P., Wilson M., and Lockhart, H., The effect of certain goitrogenic drugs on the absorption of radioactive iodine by the thyroid gland of rats and chicks. I. Collection of radioiodine by thyroids made goitrous following chronic administration of these agents. J. Pharmacol. \& Exper. Therap., 1948, 93, 240.

62. McGinty, D. A., Rawson, R. W., Fluharty, R. G., Wilson, M., Riddell, C., and Yee, H., The effect of certain goitrogenic drugs on the absorption of radioactive iodine by the thyroid gland. II. Collection of radioiodine by thyroids of rats and chicks following a single injection of these agents. J. Pharmacol. \& Exper. Therap., 1948, 93, 246.

63. Pitt-Rivers, R., The action of antithyroid substances on the formation in vitro of acetylthyroxine from acetyldiiodotyrosine. Biochim. et Biophysica Acta, 1948, 2, 311.

64. Larson, R. A., Keating, F. R., Jr., Peacock, W., and Rawson, R. W., The effect of thiouracil on the collection of radioactive iodine by the thyroid of the chick. Endocrinology, 1945, 36, 160.

65. Stanley, M. M., and Astwood, E. B., Determination of the relative activities of antithyroid compounds in man using radioactive iodine. Endocrinology, 1947, 41, 66.

66. MacKenzie, C. G., and MacKenzie, J. B., Effect of sulfonamides and thioureas on the thyroid gland and basal metabolism. Endocrinology, 1943, 32, 185.

67. Astwood, E. B., Sullivan, J., Bissell, A., and Tyslowitz, R., Action of certain sulfonamides and of thiourea upon the function of the thyroid gland of the rat. Endocrinology, 1943, 32, 210.

68. Franklin, A. L., Lerner, S. R., and Chaikoff, I. L., 
Effect of thiouracil on the formation of thyroxine and diiodotyrosine by the thyroid gland of the rat with radioactive iodine as indicator. Endocrinology, 1944, 34, 265.

69. Miller, W. H., Roblin, R. O., Jr., and Astwood, E. B., Studies in chemotherapy. XI. Oxidation of 2-thiouracil and related compounds by iodine. J. Am. Chem. Soc., 1945, 67, 2201.

70. Randall, L. O., Reaction of thiol compounds with peroxidase and hydrogen peroxide. J. Biol. Chem., 1946, 164, 521.

71. Schachner, H., Franklin, A. L., and Chaikoff, I. L., The effect of cytochrome oxidase inhibitors on the formation in vitro of thyroxine and diiodotyrosine by thyroid tissue with radioactive iodine as indicator. J. Biol. Chem., 1943, 151, 191.

72. Lerner, S. R., and Chaikoff, I. L., The influence of goitrogenic compounds (sulfonamides and their derivatives, thiourea and its derivatives) on respiration of thyroid tissue. Endocrinology, 1945, 37, 362.

73. Morton, M. E., Chaikoff, I. L., and Rosenfeld, S., Inhibiting effect of inorganic iodide on the formation in vitro of thyroxine and diiodotyrosine by surviving thyroid tissue. J. Biol. Chem., 1944, 154, 381 .

74. Wolff, J., and Chaikoff, I. L., The inhibitory action of excessive iodide upon the synthesis of diiodotyrosine and of thyroxine in the thyroid gland of the normal rat. Endocrinology, 1948, 43, 174.

75. Wolff, J., and Chaikoff, I. L., Plasma inorganic iodide, a chemical regulator of normal thyroid function. Endocrinology, 1948, 42, 468.

76. Raben, M. S. Endocrinology, in press.

77. Stanley, M. M., The effect of the iodide ion on thyroid hormone formation in man. J. Clin. Invest., 1949, 28, 812.

78. Levine, H., Remington, R. E., and von Kolnitz, H., Studies on the relation of diet to goiter. II. The iodine requirement of the rat. J. Nutrition, 1933, 6, 347.

79. Boothby, W. M., Abstract of discussion on thyrotoxicosis. J. A. M. A., 1935, 104, 980.

80. MacKenzie, C. G., Differentiation of the anti-thyroid action of thiouracil, thiourea, and p-aminobenzoic acid from sulfonamides by iodide administration. Endocrinology, 1947, 40, 137.

81. Hamilton, J. G., Soley, M. H., and Eichorn, K. B., Deposition of radioactive iodine in human thyroid tissue. Univ. California Publ., Pharmacol., 1940, 1 (28), 339.

82. Leblond, C. P., Locating iodine in tissues autographically, especially after fixation by freezing and drying. Stain Technol., 1943, 18, 159.

83. Belanger, L. F., and Leblond, C. P., A method for locating radioactive elements in tissues by covering histological sections with a photographic emulsion. Endocrinology, 1946, 39, 8.

84. Evans, T. C., Radioautographs in which the tissue is mounted directly on the photographic plate. Proc. Soc. Exper. Biol. \& Med., 1947, 64, 313.
85. Cobb, J., and Solomon, A. K., The detection of beta radiation by photographic film. Rev. Scient. Instruments, 1948, 19, 441.

86. Boyd, G. A., and Williams, A. F., Stripping film technics for histological autoradiographs. Proc. Soc. Exper. Biol. \& Med., 1948, 69, 225.

87. Leblond, C. P., Percival, W. L., and Gross, J., Autographic localization of radioiodine in stained sections of thyroid gland by coating with photographic emulsion. Proc. Soc. Exper. Biol. \& Med., 1948, 67, 74.

88. Gorbman, A., Quoted by Goldsmith. Ann. New York Acad. Sc., 1949, 50, 283.

89. Gorbman, A., and Creaser, C. W., Accumulation of radioactive iodine by the endostyle of larval lampreys and the problem of homology of the thyroid. J. Exper. Zool., 1942, 89, 391.

90. Matthews, S. A., and Smith, D. C., Concentration of radioiodine by the thyroid gland of the parrot fish. Am. J. Physiol., 1948, 153, 222.

91. Gorbman, A., and Evans, H. M., Correlation of histological differentiation with beginning of function of developing thyroid gland of frog. Proc. Soc. Exper. Biol. \& Med., 1941, 47, 103.

92. Gorbman, A., and Evans, H. M., Beginning of function in the thyroid of the fetal rat. Endocrinology, 1943, 32, 113.

93. Leblond, C. P., Histological localization of radioactive compounds in tissue as illustrated with the help of radioiodine. Recent Progress in Hormone Research (Laurentian Conf.), 1948, 3, 159.

94. Couceiro, A., Vieira, L. G., and deMoraes, J., Action of thiouracil on fixation of iodine by the thyroid. Rev. brasil. de biol., 1944, 4, 173.

95. Leblond, C. P., Fertman, M. B., Puppel, I. D., and Curtis, G. M., Radioiodine autography in studies of human goitrous thyroid glands. Arch. Path., 1946, 41, 510.

96. McArthur, J. W., and Cope, O., The functional capacity of thyroid tumors as judged by radioactive iodine uptake. J. Clin. Invest., 1946, 25, 929.

97. Dobyns, B. M., and Lennon, B., A study of the histopathology and physiologic function of thyroid tumors, using radioactive iodine and radioautography. J. Clin. Endocrinol., 1948, 8, 732.

98. Leblond, C. P., Puppel, I., D., Riley, E., Radike, M., and Curtis, G. M., Radioiodine and iodine fractionation studies of human goitrous thyroids. J. Biol. Chem., 1946, 162, 275.

99. Puppel, I. D., Leblond, C. P., and Curtis, G. M., The surgical therapeutic significance of the functional behaviour of thyroid nodules. Ann. Surg., 1947, 125, 257.

100. Kendall, E. C., A method for the decomposition of the proteins of the thyroid, with a description of certain constituents. J. Biol. Chem., 1915, 20, 501.

101. Harington, C. R., Thyroxine: its biosynthesis and its immunochemistry. Proc. Roy. Soc. London, 1944, B132, 223.

102. Taurog, A., and Chaikoff, I. L., The nature of the 
circulating thyroid hormone. J. Biol. Chem., 1948, 176, 639.

103. Salter, W. T., The circulating thyroid hormone in blood and lymph. West. J. Surg., 1947, 55, 15.

104. Salter, W. T., The Endocrine Function of Iodine. Harvard Univ. Press, Cambridge, 1940.

105. Frieden, E., and Winzler, R. J., Comparative parenteral thyroxine-like activity of natural and synthetic thyroproteins studied with the goiterprevention method. Endocrinology, 1948, 43, 40.

106. Hamilton, C. F., Albert, A., and Power, M. H., Bio-assay of calorigenic substances using tadpoles of xenopus laevis. Endocrinology, 1948, 43, 406.

107. de Robertis, E., Proteolytic enzyme activity of colloid extracted from single follicles of the rat thyroid. Anat. Rec., 1941, 80, 219.

108. Dziemian, A. J., Proteolytic activity of the thyroid gland. J. Cell. \& Comp. Physiol., 1943, 21, 339.

109. Stanley, M. M., and Astwood, E. B., The response of the thyroid gland in normal human subjects to the administration of thyrotropin as shown by studies with $\mathrm{I}^{131}$. Endocrinology, 1949, 44, 49.

110. Keating, F. R., Jr., Rawson, R. W., Peacock, W., and Evans, R. D., The collection and loss of radioactive iodine compared with the anatomic changes induced in the thyroid of the chick by the injection of thyrotropic hormone. Endocrinology, 1945, 36, 137.

111. Dempsey, E. W., and Astwood, E. B., Determination of the rate of thyroid hormone secretion at various environmental temperatures. Endocrinology, 1943, 32, 509.

112. Joliot, F., Courrier, R., Horeau, A., and Süe, P., Sur la préparation d'une hormone contenant des atomies radioactifs. Compt. rend. Soc. de Biol., 1944, 138, 325.

113. Gross, J., and Leblond, C. P., Distribution of a large dose of thyroxine labelled with radioiodine in the organs and tissues of the rat. J. Biol. Chem., 1947, 171, 309.

114. Chaikoff, I. L., Taurog, A., and Reinhardt, W. O., The metabolic significance of protein-bound iodine of plasma: A study of its concentration under various conditions and of its rate of formation as measured with radioactive iodine. Endocrinology, 1947, 40, 47.

115. Taurog, A., Chaikoff, I. L., and Entenman, C., The rate of turnover of protein-bound iodine in the plasma of the dog as measured with radioactive iodine. Endocrinology, 1947, 40, 86.

116. Rawson, R. W., Evans, R. D., Means, J. H., Peacock, W. C., Lerman, J., and Cortell, R. E., The action of thiouracil upon the thyroid gland in Graves' disease. J. Clin. Endocrinol., 1944, 4, 1.

117. Leiter, L., Seidlin, S. M., Marinelli, L. D., and Baumann, E. J., Adenocarcinoma of the thyroid with hyperthyroidism and functional metastases. I. Studies with thiouracil and radioiodine. J. Clin. Endocrinol., 1946, 6, 247.
118. Seidlin, S. M., Marinelli, L. D., and Oshry, E., Radioactive iodine therapy. Effect on functioning metastases of adenocarcinoma of the thyroid. J. A. M. A., 1946, $132,838$.

119. Rawson, R. W., Marinelli, L. D., Skanse, B. N., Trunnell, J., and Fluharty, R. G., The effect of total thyroidectomy on the function of metastatic thyroid cancer. J. Clin. Endocrinol., 1948, 8, 826.

120. Hertz, S., and Roberts, A., Radioactive iodine in the study of thyroid physiology. VII. The use of radioactive iodine therapy in hyperthyroidism. J. A. M. A., 1946, 131, 81.

121. Chapman, E. M., and Evans, R. D., Treatment of hyperthyroidism with radioactive iodine, J. A. M. A., 1946, $131,86$.

122. Skanse, B., Radioactive iodine: its use in studying the urinary excretion of iodine by humans in various states of thyroid function. Acta. med. Scandinav., 1948, 131, 251.

123. Oshry, E., and Schmidt, C., Radioiodine uptake and excretion measurements and their significance. Brookhaven Conf. Rep., July 1948, BNL-C-5, 50.

124. Keating, F. R., Jr., Power, M. H., Berkson, J., and Haines, S. F., The urinary excretion of radioiodine in various thyroid states. J. Clin. Invest., 1947, 26, 1138.

125. Quimby, E. H., and McCune, D. J., Uptake of radioactive iodine by the normal and disordered thyroid gland in children. Radiology, 1947, 49, 201.

126. Hamilton, J. G., and Soley, M. H., Studies on iodine metabolism of the thyroid gland in situ by the use of radio-iodine in normal subjects and in patients with various types of goiters. Am. J. Physiol., 1940, 131, 135.

127. Feitelberg, S., Kaunitz, P. E., Wasserman, L. R., and Yohalem, S. B., The use of radioactive iodine in the diagnosis of thyroid disease. Am. J. Med. Sc., 1948, 216, 129.

128. Astwood, E. B., and Stanley, M. M., Use of radioactive iodine in the study of thyroid function in man. West. J. Surg., 1947, 55, 625.

129. Werner, S. C., Quimby, E. H., and Schmidt, C., Radioactive iodine in the treatment of toxic goiter and as an indicator of thyroid function in man. Brookhaven Conf. Rep., July 1948, BNL-C-5, 69.

130. Stanley, M. M., and Astwood, E. B., 1-Methyl-2mercaptoimidazole: An antithyroid compound highly active in man. Endocrinology, 1949, 44, 588.

131. Greer, M. A., and Astwood, E. B., The antithyroid effect of certain foods in man as determined with radioactive iodine. Endocrinology, 1948, 43, 105.

132. Astwood, E. B., Greer, M. A., and Ettlinger, M. G., The antithyroid factor of yellow turnip. Science, 1949, 109, 631.

133. Stanley, M. M., Unpublished, 1948.

134. Means, J. H., The use of radioactive iodine in the diagnosis and treatment of thyroid diseases. Bull. N. Y. Acad. Med., 1948, 24, 273. 